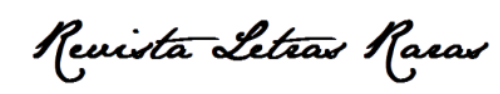

ISSN: 2317-2347 - v. 9, n. 2 (2020)

Todo o conteúdo da RLR está licenciado sob Creative Commons Atribuição 4.0 Internacional

\title{
A falta do jindungozinho
}

\section{Higor Lima da Silva*}

Graduando no curso de ABI Letras Português-Francês, na Universidade Federal de São Paulo - EFLCH. Guarulhos-SP, Brasil.

\section{iD https://orcid.org/0000-0002-9599-1729}

Recebido: 06 abr. 2020. Aprovado: 01 jun. 2020.

Como citar este poema:

LIMA DA SILVA, Higor. A falta do jindungozinho. Revista Letras Raras, v. 9, n. 2, p. 325-326, jun. 2020.

Clamo-te pela tua presença, ó Charles, tu que só, somente não fracassaste na escrita. Invoco-te para que sejas minha testemunha e me auxilies a ser justo com esse "réu", o vagabundo "ladrãozinho". Esse que "não tem lar", que é pobre, que veste borra... que é escarrado com efusiva ojeriza! "Esse daí", onde nem a linda musa dos desocupados ousa olhar com magnânimo afecto. Ó, Castro Alves, Deus nem mesmo respondes-te, ou respondeu-me, do porquê de tamanho horror diante dos céus...

Todavia, decerto, digo-te... minha amada... que quando falas que amas-me, e que 0 amor fizeste redimir-se da rispidez, tua boca exalas o cheiro do leite da tua mãe. Dissimuladas palavras! Como podes ter ficado doce, se se recusas a efetivamente olhar o vagabundo? Ah! Tua distância de minha consciência dói-me o cérebro! A ponto de que, para que a reminiscência não se prolongue, e esta azeda tristeza que sinto alquimia-se à alegria, seria melhor se tu tivesses me jogado desse parapeito do que ter dito àquilo...

Quão distante são nossos pensamentos? Para onde foram as juras de amor de ontem? Enquanto enamoro teus olhos de âmbar, teu cabelo castanho e curto seguindo o vento, que me apraz com o inigualável cheiro do teu Classique... tu olhas apenas a rua, mas só observas as joias das vitrines ambulantes, os carros de monte, os arranha-céus, o consumo imperativo... mas nunca o coitado do vagabundo da Ladeira da Memória, esse: "sem lar", que varre a rua

\. higorlimadasilva@hotmail.com

doi http://dx.doi.org/10.35572/rlr.v9i2.1753 


\section{Revista Letear Racar}

ISSN: $2317-2347$ - v. 9 , n. 2 (2020)

Todo o conteúdo da RLR está licenciado sob Creative Commons Atribuição 4.0 Internacional

engolida pela multidão, de máquinas e, de pessoas desprovidas de jindungozinho. De pessoas tão blasés.

Amor é fraqueza. Tu queres o que pertence à fama. Esqueces do rio de sangue, rubro, denso, estático, frio, melancólico; da única lágrima, uníssona, que anda na sola dessa multidão que veste lustres nos pés. Ó, pobre pulsante, o mundo já tem muita tristeza, não fique aqui, parado, para humilhar-se; se entregue à prostituta, aos desesperançosos, aos desacolhidos, ao vadiar que é, em si, um caminho virtuoso, de verdadeira alegria; seja um matador dos sofridos! 